\title{
Diversity and Species Composition of Subaerial Algal Communities in Forested Areas of Meghalaya, India
}

\author{
Diana Kharkongor and Papiya Ramanujam \\ Algal Ecology Laboratory, Centre for Advance Studies in Botany, Department of Botany, School of Life Sciences, \\ Northeastern Hill University, Shillong, Meghalaya 793022, India
}

Correspondence should be addressed to Diana Kharkongor; dianakharkongor@gmail.com

Received 26 September 2013; Revised 16 December 2013; Accepted 16 December 2013; Published 28 January 2014

Academic Editor: Rafael Riosmena-Rodríguez

Copyright (C) 2014 D. Kharkongor and P. Ramanujam. This is an open access article distributed under the Creative Commons Attribution License, which permits unrestricted use, distribution, and reproduction in any medium, provided the original work is properly cited.

\begin{abstract}
The study deals with a comparative study on diversity and species composition of subaerial algal communities from tree barks of closed undisturbed sacred grove, mixed plantation, and open disturbed forest. A total of 85 taxa had been recorded, 30 cyanobacteria and 55 algal species belonging to six classes of algae. Sacred grove harboured the highest subaerial algal diversity compared to those of plantation and open disturbed forest. There was a strong significant difference in species composition among the three different sampling areas. High number of diatoms with 14 species was recorded in sacred grove. Cyanobacteria with 22 species were the frequent group in disturbed forest whereas Trentepohliales dominated in plantation. Canonical correspondence analysis confirmed that high photon irradiance favored the growth of cyanobacteria in disturbed forest. The abundance of Trentepohliales members correlated to high rainfall and photon irradiance. High diversity and presence of many diatom species in undisturbed Mawphlang sacred grove were associated with low photon irradiance and high relative humidity and could also be due to a presence of suitable substrata formed by the growth of mosses. Sunlight, relative humidity, and rainfall were the important factors which played a major role in determining the diversity and distribution of subaerial algal communities.
\end{abstract}

\section{Introduction}

Subaerial algae grow luxuriantly in Meghalaya and their presence impart yellowish or reddish orange colour to most of the tree barks, walls, and rocks. Meghalaya experiences high rainfall and high humidity which provides ideal condition for the growth of subaerial algal communities the whole year around. With the rapid disappearance of trees in forests, mainly due to urbanisation and shifting cultivation, it is important to record the diversity of microalgal communities in subaerial habitats in this region. Studies on subaerial algae growing in different habitats had been carried out since the 19th century [1-5]. Terrestrial microscopic green algae are the most widespread but the least known and most overlooked amongst all algal groups [6, 7]. By and large, compared with that of fresh water and marine algae, the knowledge on diversity and distribution of algae and cyanobacteria in subaerial habitats is very scanty and lags far behind [8]. Besides cyanobacteria and coccoid green algae, Trentepohliales members formed the main component of terrestrial flora in the world especially in areas with humid climates where they were growing on wide range of habitats [9-11]. In the recent years, some extensive taxonomical and diversity works had been carried out on subaerial algae but they were usually concentrated on Trentepohliales, a dominant group in subaerial habitat [12-16]. However, Neustupa and Škaloud $[8,17]$ reported the diversity of other groups, mainly Chlorococcales and cyanobacteria along with Trentepohliales; they also reported the significant role of light on the diversity of subaerial algae and cyanobacteria. Works on subaerial algae were also carried out by various workers in subtropical and temperate forests [18-20]. In Indian context, information on subaerial algae is scanty and few reports are available from Kerala, Nilgiris, West Bengal, Assam, and neighbouring Bangladesh [21-27].

Meghalaya with a geographical area of $22,429 \mathrm{~km}^{2}$ lies in the northeastern region of India. It lies between latitudes $20.1^{\circ}-26.5^{\circ} \mathrm{N}$ and longitudes $85.49^{\circ}-92.52^{\circ} \mathrm{E}$. The elevation ranges from $60 \mathrm{~m}$ a.s.l. to $1,950 \mathrm{~m}$ a.s.l. The state experiences 
a typical monsoon climate with average annual rainfall as high as $1200 \mathrm{~cm}$ in some areas. Its climate is directly influenced by the southwest monsoon and the northeast winter winds. The four main seasons of Meghalaya are spring, monsoon, autumn, and winter. Spring usually runs from March to April. Monsoon usually starts by mid-May and continues right to the end of September and sometimes well into the middle of October. October and November are the transition months between rainy and winter seasons. The period between December and February is winter and is characterized by cold and dry weather. Meghalaya with its diverse climatic and topographic conditions supports many forests with a wide variety of floral diversity. Very little is known about the diversity and species composition of subaerial algae from Meghalaya which is a hot spot diversity region. Hence, the present work has been carried out to enumerate the diversity and species composition of subaerial algal communities growing on tree barks in this region, in relation to environmental parameters. Trees from three sites with different levels of disturbances and situated at different locations with a considerable distance from each other were sampled for this work. This study also aimed at investigating the effect of sampling areas and the role of photochromic elements like the sunlight and other environmental factors in determining the diversity and distribution of subaerial algae and cyanobacteria.

\section{Material and Methods}

2.1. Study Sites. Three different sites were selected for sampling in and around Shillong, the capital of Meghalaya:

(1) Mawphlang sacred grove (MSG) is an undisturbed subtropical broad leaf hill forest lying at an altitude of $1646-1710 \mathrm{~m}$ a.s.l and latitude $-25^{\circ} 26.707^{\prime} \mathrm{N}$, $91^{\circ} 44.906^{\prime} \mathrm{E}$ to $25^{\circ} 26.709^{\prime} \mathrm{N}, 91^{\circ} 44.913^{\prime} \mathrm{E}$; this sacred forest is located about 25 kilometers southwest from Shillong and covers an area of about $67.8 \mathrm{ha}$; it has been preserved and protected from any human interferences by the local people through traditional religious sanction since ancient times, and it is composed of evergreen broad leaf trees which are more than a hundred years old and usually covered with mosses and other epiphytes. The common trees recorded from the grove were Castanopsis sp, Quercus sp., Rhododendron arboreum Smith, Symplocos sp, Viburnum simonsii Hook. f. and Thomson, Myrica sp, Ficus sp, and so forth. The thick canopy allows little amount of sunlight to penetrate inside the grove. The photon irradiance measured inside the grove ranges from 17 to $51 \mu \mathrm{mol} \mathrm{m}^{-2} \mathrm{~s}^{-2}$;

(2) Shillong Golf Course Plantation (SGC) is lying at an altitude of $1440-1448 \mathrm{~m}$ a.s.l, latitude $-25^{\circ} 35.180^{\prime} \mathrm{N}$, $91^{\circ} 53.789^{\prime} \mathrm{E}$ to $25^{\circ} 35.182^{\prime} \mathrm{N}, 91^{\circ} 53.791^{\prime} \mathrm{E}$ and the mixed plantation surrounding the Shillong golf course is composed mainly of Eucalyptus sp, Grevillea sp, Jacaranda sp, Alnus sp, Cryptomeria sp, Albizia $\mathrm{sp}$, and prunus sp. and receives photon irradiance ranging from 76 to $158 \mu \mathrm{mol} \mathrm{m}{ }^{-2} \mathrm{~s}^{-2}$;
(3) Umiam disturbed forest, lying at an altitude of 958$1098 \mathrm{~m}$ a.s. 1 and latitude- $25^{\circ} 39.628^{\prime} \mathrm{N}, 91^{\circ} 54.293^{\prime} \mathrm{E}$ to $25^{\circ} 39.109^{\prime} \mathrm{N}, 91^{\circ} 53.880^{\prime} \mathrm{E}$, is located about $18 \mathrm{Km}$ from Shillong. This sampling area lies beside the National Highway-44 (NH-44) and is disturbed due to various anthropogenic interferences. Pinus kesiya Royle ex Gordon was the most common tree species in this area. Other common tree species were Acacia sp, Schima wallichii (DC.) Korth (Chilaune), Prunus sp, Alnus sp, Albizia sp, and Jacaranda sp. The area receives high photon irradiance ranging from 272 $460 \mu \mathrm{mol} \mathrm{m}{ }^{-2} \mathrm{~s}^{-2}$.

2.2. Field Sampling. Algal samples were collected on a monthly basis from the bark of 20 randomly chosen trees from each site covering an area of about 1 ha from January 2012 to December 2012. Bark samples measuring $1 \mathrm{~cm}^{2}$ were collected with the help of a sterile knife from around the tree trunk at a height of $1.5 \mathrm{~m}$ above the ground. Care was taken to ensure that there was no cross-contamination between samples by sterilising the knife after each sample collection. The collected algal samples were then properly sealed in plastic bags and brought to the laboratory for further detailed studies.

2.3. Data Analyses. Samples from $1 \mathrm{~cm}^{2}$ area were homogenized and inoculated in Modified Bold's Basal medium and BG-11 medium within 48 hours after collection. Samples were cultivated in liquid medium in conical flasks at a temperature of $25^{\circ} \mathrm{C}$ and an illumination of $40 \mu \mathrm{mol} \mathrm{m}^{-2} \mathrm{~s}^{-2}$ provided by $20 \mathrm{~W}$ cool fluorescent tubes. Direct examination of field samples was carried out for assessment of diversity. Each sample was observed under Olympus BX41 light microscope and was microphotographed with the help of Olympus digital camera fitted directly to the microscope. Identification was done following standard books, monographs, and papers of Printz [4], Smith [28], Desikachary [29], Cox [30], Gandhi [31], Krishnamurthy [23], John et al. [32], Rindi and Guiry [15], Rindi et al. [16], Rindi et al. [33], Neustupa and Škaloud $[8,17]$, and Škaloud $[34,35]$. Species diversity was calculated using the Shannon-Wiener diversity index [36], following the formula

$$
\mathbf{H}^{\prime}=\sum_{i=1}^{s} p_{i} \ln p_{i}
$$

where $p_{i}=n_{i} / N, n_{i}=$ no. of individuals in the $i$ th species; $N=$ Total number of individuals of all species.

The different environmental parameters data prevailing on each of the sampling sites from January 2012 to December 2012 were recorded. Parameters such as photon irradiance, temperature, and relative humidity were recorded at the time of sampling by a digital Luxmeter, Thermometer, and Hygrometer, respectively. Monthly data of rainfall prevailing in the sampling areas were collected from nearby meteorological observatory of I.C.A.R Research Complex for northeastern Hill Region, Umiam, Agricultural Research Centre Shillong, and Meteorological Centre Upper Shillong. 
2.4. Statistical Analyses. nMDS (nonmetric multidimensional scaling) ordination plot was used in order to illustrate the similarities in algal species composition collected from three different sampling areas, and this was carried out in PAST software version 1.93 [37]. Significance of differences in species composition among the three different sites was assessed by nonparametric one way ANOSIM (Analysis of similarities) by using Bray-Curtis distance measure with 9999 permutations.

SIMPER (similarity percentage) was used to detect the percentage contribution of each species to the observed dissimilarity amongst sites where it identified the species that were most important in creating the observed pattern of dissimilarity. The method used the Bray-Curtis measure of similarity which was carried out in PAST software.

Canonical Correspondence Analysis (CCA) was employed in order to explain the correlation of species to specific environmental variables [38]. For this purpose, the species abundance was taken into account. Taxa abundances were $\log$ transformed and environmental variables were square root transformed. CCA was performed using statistical package XLSTAT version 2009.

Two-way analysis of variance (ANOVA) was used to find out the significant differences in environmental parameters which prevailed in the different sites and one-way ANOVA was carried out to see the significant difference in diversity between the sites. These analyses were carried out in Microsoft Office Excel 2007.

\section{Results}

3.1. Environmental Parameters. The environmental parameters like photon irradiance, relative humidity, and temperature recorded from January 2012 to December 2012 varied significantly in between three sampling sites except for rainfall (Table 1). Illumination was maximum in open disturbed forest in Umiam beside the National Highway44 where it ranged from 272 to $460 \mu \mathrm{mol} \mathrm{m}{ }^{-2} \mathrm{~s}^{-2}$, followed by plantation in Shillong Golf Course $\left(76-158 \mu \mathrm{mol} \mathrm{m}^{-2} \mathrm{~s}^{-2}\right)$, and minimum in closed undisturbed sacred grove (17$51 \mu \mathrm{mol} \mathrm{m}{ }^{-2} \mathrm{~s}^{-2}$ ). Relative humidity also differed in three sites where humidity was noted to be maximum in open forest of Umiam (77\%-90.0\%), in sacred grove relative humidity ranged from $54 \%-88 \%$, and it was minimum in plantation in Golf course (49.6\%-63.26\%). Temperature was the maximum in $\mathrm{NH}-44$ and ranged from $11.9^{\circ} \mathrm{C}$ to $24.55^{\circ} \mathrm{C}$, in plantation in golf course it was $11.6^{\circ} \mathrm{C}-23.69^{\circ} \mathrm{C}$, and it was minimum in closed sacred grove $\left(9.6^{\circ} \mathrm{C}-21.55^{\circ} \mathrm{C}\right)$. In case of rainfall, Mawphlang sacred grove experienced the highest rainfall with total annual rainfall of $2767.1 \mathrm{~mm}$. In Golf course it was $2104.8 \mathrm{~mm}$ of rainfall and disturbed forest in Umiam received $2086.4 \mathrm{~mm}$ of total annual rainfall. The monthly environmental parameters prevailing in the three sites are given in Figure 1.

3.2. Diversity and Species Composition. A total of 85 taxa had been recorded, 55 algal species belonging to six classes of algae, that is, Bacillariophyceae, Chlorophyceae, Trebouxiophyceae, Klebsormidiophyceae, Ulvophyceae, and Zygnematophyceae, and 30 cyanobacteria were recorded from the three different selected sites (Table 2). Out of a total of 85 species, 27 taxa were recorded exclusively from closed undisturbed sacred grove, only 8 taxa were found exclusively in plantation in Shillong Golf Course, and 16 taxa mainly cyanobacteria belonged exclusively to Umiam disturbed forest beside the NH-44. Only 12 taxa were noted to be common to all the three sites. Closed Mawphlang sacred grove where relative humidity was high and tree barks usually covered by mosses showed a higher number of diatoms represented by 14 species whereas Trebouxiophyceae members were more in plantation in Shillong Golf Course. Cyanobacteria with 22 species dominated in open disturbed forest in Umiam where the photon irradiance was the highest and trees were covered with dust and soot.

Diversity index in sacred grove ranges from 0.98 in May to 2.95 in February whereas in open disturbed forest July has lowest diversity with 1.08 and February showed the highest with 2.19. In plantation in Golf Course, September showed lowest diversity index of 0.98 , and February, with 2.14 has the highest diversity. Figure 2 showed the ranges of diversity in the twelve months in all the three sites. A common pattern was observed in all the three sites whereby the highest diversity was in the month of February. Taken as mean of all the twelve months in all the three sites closed undisturbed Mawphlang sacred grove with highest rainfall and lowest photon irradiance harboured the highest diversity (1.94) compared to that of open disturbed forest lying beside the NH-44 in Umiam (1.66) and mixed plantation in Golf course (1.44). However, there were no significant differences in diversity between sacred grove and disturbed forest and between disturbed forest and mixed plantation. Significant difference in diversity was noted only between sacred grove and plantation in Shillong Golf Course $(P=0.027)$.

The nMDS ordination (Figure 3 ) clearly illustrated the differences in species composition in three different selected sites by forming three different clusters. Comparing within the groups, most of the samples collected from plantations in Golf course were very much similar to each other and hence arranged closely to one another, whereas samples collected from Mawphlang sacred grove were of diverse type and showed some variation in composition. Samples collected from NH-44 Umiam formed two different clusters but they were arranged closer to one another. Significant differences in species composition in three contrasting sites was further confirmed through ANOSIM which showed strong significant differences among the samples from these three sampling areas (mean rank within group $=140.4$, mean rank between groups $=395.8, R=0.8107, P=0.0001$ ).

SIMPER analysis showed a high dissimilarity in species composition among the three sites with an overall dissimilarity of $73.46 \%$ and the species that were responsible for the observed pattern of dissimilarity were also indicated (Table 3). The sacred grove was distinguished from the other two sites by the presence of Trentepohlia sp. 1, Trentepohlia sp. 2, Trentepohlia sp. 5 and mainly diatoms such as Eunotia praerupta Ehrenberg, Eunotia exigua (Brébisson 
TABLE 1: ANOVA table to show the variations in environmental parameters among sampling areas.

\begin{tabular}{lcccc}
\hline & Photon irradiance $\left(\mu \mathrm{mol} \mathrm{m}^{-2} \mathrm{~s}^{-2}\right)$ & Rainfall $(\mathrm{mm})$ & Relative humidity $(\%)$ & Temperature $\left({ }^{\circ} \mathrm{C}\right)$ \\
\hline$P$-value & $3.11 E-07^{*}$ & 0.91 & $3.01 E-11^{*}$ & $0.00078^{*}$ \\
$F$-value & $118.80^{*}$ & 0.01 & $681.83^{*}$ & $20.99^{*}$ \\
\hline
\end{tabular}

${ }^{*}$ Indicates significant difference at $P<0.05$.

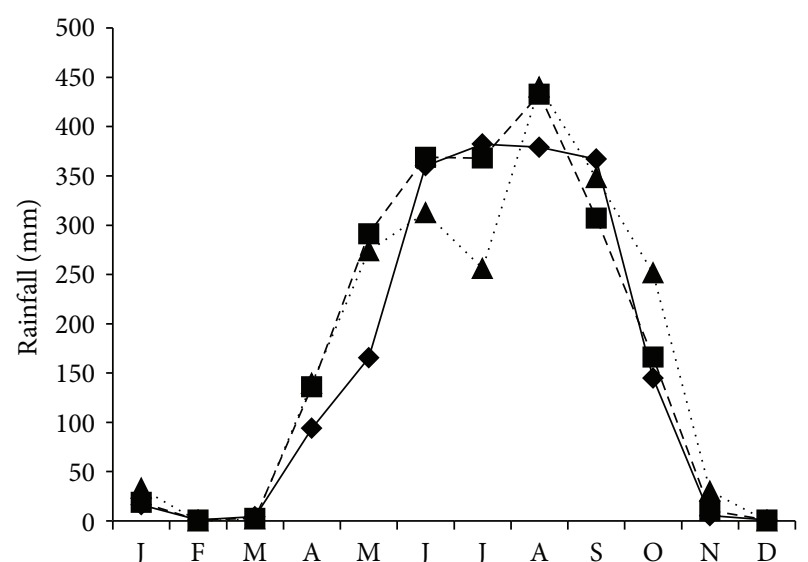

(a)

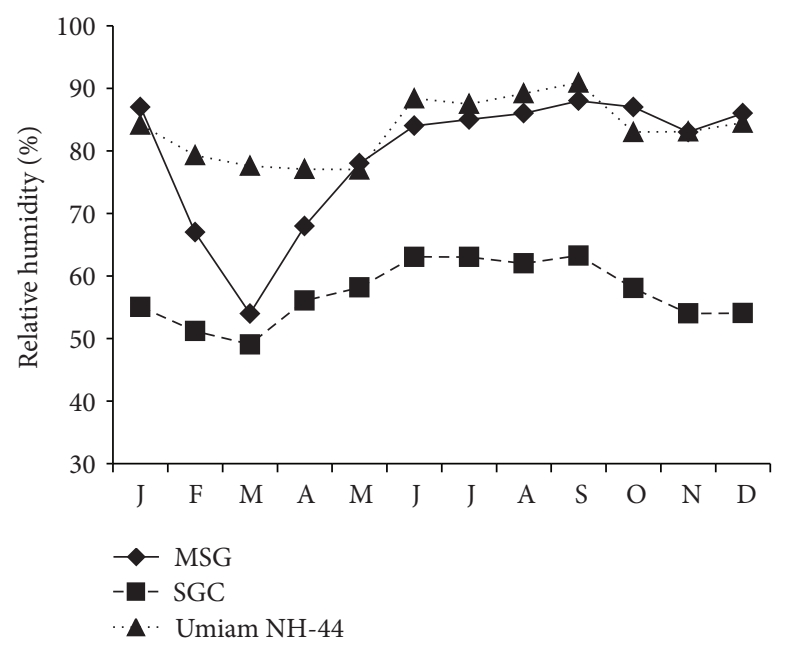

(c)

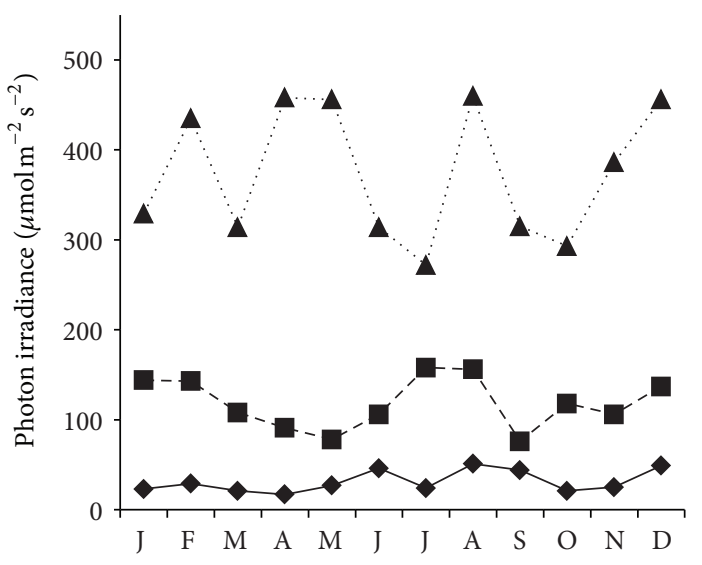

(b)

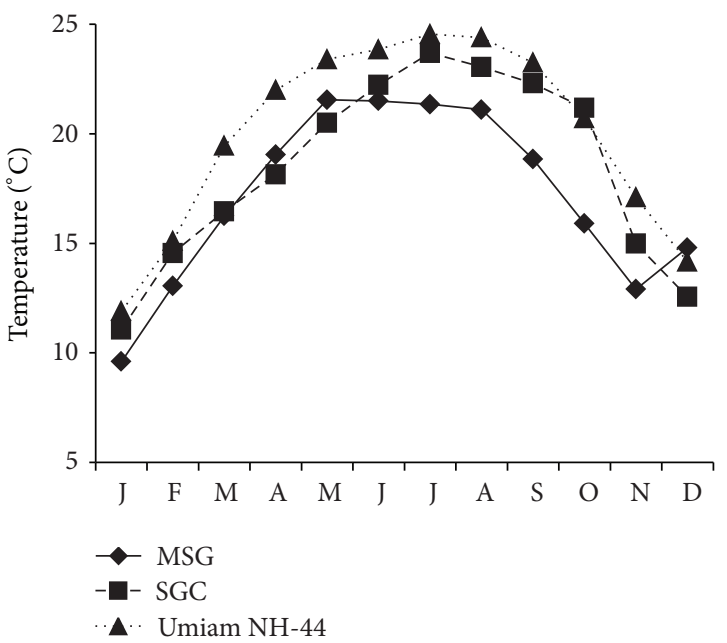

(d)

FIGURE 1: Environmental variables, that is, rainfall, photon irradiance, relative humidity and temperature recorded from January to December 2012 in the three selected sampling sites (sacred grove in Mawphlang (MSG), mixed plantation in Shillong golf course (SGC), and disturbed forest in Umiam beside NH-44 (Umiam-NH44)).

ex Kützing) Rabenhorst, Cocconeis placentula Ehrenberg, Achnanthes lanceolata (Brébisson ex Kützing) Grunow, and Melosira dickiei (Thwaites) Kutzing. Presence of Trentepohlia sp. and mainly cyanobacteria like Scytonema sp. 1, Gloeocapsa punctata Nägeli, Scytonema millei Bornet, Gloeocapsa sp, Aphanocapsa muscicola (Meneghini) Willa and Aphanothece sp. differentiated the closed disturbed forest in Umiam beside the NH-44 from others. Desmococcus olivaceus (Persoon ex Acharius) J.R. Laundon, Trentepohlia abietina (Flotow) Hansgirg, Chlorella sp, Chlorella saccharophila (W. Kruger) Migula, Mesotaenium macrococcum (Kutzing ex Kutzing) J. Roy \& bisset, Trentepohlia rigidula (J. Müller) Hariot,
Euastrum sublobatum var. dissimile (Nordstedt) West and G.S. West and Trebouxia arboricola De Puymalywere more abundant in plantation in Golf Course than at the other sites.

CCA (Canonical Correspondence Analysis) of species abundance data with environmental variables produced an ordination where the first two axes were statistically significant $(P<0.0001)$ with Eigen values 0.22 and 0.18 for F1 and F2, respectively. Since the total inertia was higher in F1 (7.54) and followed by F2 (6.17); hence, F1 and F2 were considered for constructing the CCA biplot (Figures 4 and 5). The CCA biplot explained that disturbed forest in Umiam correlated with high photon irradiance and relative 
TABLE 2: List of taxa recorded from tree barks in three different sampling areas, that is, closed undisturbed sacred grove in Mawphlang (MSG), mixed plantation in Shillong golf course (SGC), and open disturbed forest in Umiam besides NH-44 (U-NH44). (+) indicates presence.

\begin{tabular}{|c|c|c|c|c|c|}
\hline & & Species code & MSG & SGC & U-NH44 \\
\hline & \multicolumn{5}{|l|}{ CYANOBACTERIA } \\
\hline 1 & Anabaena sp. & Ana sp & + & & \\
\hline 2 & Aphanocapsa elachista West and G. S. West & A ela & & & + \\
\hline 3 & Aphanocapsa muscicola (Meneghini) Willa & A mus & & + & + \\
\hline 4 & Aphanocapsa sp. & A sp & & & + \\
\hline 5 & Aphanothece sp. & Aph sp & & & + \\
\hline 6 & Aphanothece sp. 1 & Aph 1 & & + & + \\
\hline 7 & Gloeocapsa alpina (Nägeli) Brand & Gle a & & & + \\
\hline 8 & Gloeocapsa punctata Nägeli & Gle $\mathrm{p}$ & & + & + \\
\hline 9 & Gloeocapsa sanguinea (C. Agardh) Kützing & Gle s & & & + \\
\hline 10 & Gloeocapsa sp. & Gle sp & & & + \\
\hline 11 & Lyngbya martensiana (Meneghini) Gomont & Lyn mar & & & + \\
\hline 12 & Nostoc muscorum C. Agardh ex Bornet and Flahault & Nos $m$ & & + & + \\
\hline 13 & Nostoc punctiforme (Kützing) Hariot & Nos $\mathrm{p}$ & & & + \\
\hline 14 & Nostoc sphaericum Vaucher ex Bornet and Flahault & Nos s & & & + \\
\hline 15 & Nostoc sp. & Nos sp & + & & \\
\hline 16 & Nostoc sp. 1 & Nos 1 & + & & \\
\hline 17 & Nostoc sp. 2 & Nos 2 & + & & \\
\hline 18 & Phormidium papyraceum (C. Agardh) Gomont & Ph pap & + & & \\
\hline 19 & Phormidium sp. 1 & $\mathrm{Ph} 1$ & & & + \\
\hline 20 & Phormidium sp. 2 & $\mathrm{Ph} 2$ & & & + \\
\hline 21 & Scytonema millei Bornet & Scy mil & & & + \\
\hline 22 & Scytonema mirabile (Dillwyn) Bornet & Scy mir & & + & \\
\hline 23 & Scytonema ocellatum Lyngbye ex Bornet and Flahault & Scy oc & & + & \\
\hline 24 & Scytonema sp. & Scy sp & + & + & + \\
\hline 25 & Scytonema sp. 1 & Scy 1 & & & + \\
\hline 26 & Stigonema mamillosum (Lyngbye) C. Agardh, Bornet, and Flahault & Sti ma & + & & + \\
\hline 27 & Stigonema minutum (C. Agardh) Hassall, Bornet, and Flahault & Sti mi & + & & + \\
\hline 28 & Stigonema ocellatum (Dillwyn) Thuret, Bornet, and Flahault & Sti oc & & & + \\
\hline 29 & Symploca muscorum (C. Agardh) Gomont & Sym mus & + & & \\
\hline \multirow[t]{2}{*}{30} & Synechococcus aeruginosus Nägeli & Syn ea & + & & \\
\hline & BACILLARIOPHYCEAE & & & & \\
\hline 1 & Achnanthes lanceolata (Brébisson ex Kützing) Grunow & Acn lan & + & & \\
\hline 2 & Cocconeis placentula Ehrenberg & Coc pla & + & & \\
\hline 3 & Diadesmis sp. & Dia sp & + & & \\
\hline 4 & Eunotia exigua (Brébisson ex Kützing) Rabenhorst & Eun exi & + & & \\
\hline 5 & Eunotia praerupta Ehrenberg & Eun prae & + & & \\
\hline 6 & Eunotia sp. & Eun sp & + & & \\
\hline 7 & Frustulia rhomboides (Ehrenberg) De Toni & Fru rho & + & & \\
\hline 8 & Gomphonema lanceolatum C. Agardh & Gom lan & + & & \\
\hline 9 & Gomphonema sp. & Gom sp & + & & + \\
\hline 10 & Hantzschia amphioxys (Ehrenberg) Grunow & $\mathrm{H}$ amp & & & + \\
\hline 11 & Melosira dickiei (Thwaites) Kutzing & Mel dic & + & & \\
\hline 12 & Navicula gracilis Ehrenberg & Nav g & + & & + \\
\hline 13 & Navicula sp. & Nav sp & + & & \\
\hline 14 & Nitzschia sp. & Nitz sp & + & + & \\
\hline 15 & Pinnularia borealis Ehrenberg & Pin bor & + & & + \\
\hline
\end{tabular}


TABLe 2: Continued.

\begin{tabular}{|c|c|c|c|c|c|}
\hline & & Species code & MSG & SGC & U-NH44 \\
\hline & \multicolumn{5}{|l|}{ CHLOROPHYCEAE } \\
\hline 1 & Bracteacoccus grandis Bischoff and Bold & Bra gr & + & & \\
\hline 2 & Bracteacoccus sp. & Bra sp & + & & \\
\hline 3 & Chlorococcum sp. & Chlor sp & + & & \\
\hline 4 & Chlorococcum sp. 1 & Chlor 1 & & + & \\
\hline 5 & Chlorolobion braunii Nägeli Komarek & Chl b & + & + & + \\
\hline 6 & Gloeocystis ampla (Kützing) Rabenhorst & Gl amp & + & & \\
\hline 7 & Gloeocystis sp. & Gl sp & & & + \\
\hline 8 & Microspora sp. & Mic sp & + & + & \\
\hline 9 & Microspora sp. 1 & Micl & & + & \\
\hline \multirow[t]{2}{*}{10} & Scotiellopsis oocystisformis (Lund) Punčochářová and Kalina & Scot oocy & + & & + \\
\hline & TREBOUXIOPHYCEAE & & & & \\
\hline 1 & Chlorella vulgaris Beijerinck & Chlo vul & + & & \\
\hline 2 & Chlorella saccharophila (W. Kruger) Migula & Chlo sac & + & + & + \\
\hline 3 & Chlorella sp. & Chlo sp & + & + & + \\
\hline 4 & Chlorella sp. 1 & Chlo 1 & & + & + \\
\hline 5 & Desmococcus olivaceus (Persoon ex Acharius) J. R. Laundon & Des o & + & + & + \\
\hline 6 & Dictyochloropsis splendida (Geitler) Tschermak-Woess & Dic s & + & & \\
\hline 7 & Dictyochloropsis sp. & Dic sp & + & + & + \\
\hline 8 & Dictyochloropsis sp. 1 & Dic 1 & & + & + \\
\hline 9 & Monoraphidium sp. & Mono sp & & + & \\
\hline 10 & Podohedra saltans J. Neustupa & Pod s & & + & + \\
\hline 11 & Podohedra tropica J. Neustupa & Pod $t$ & & + & + \\
\hline 12 & Stichococcus minor Nägeli & Stic m & & + & \\
\hline 13 & Trebouxia arboricola De Puymaly & Tre a & + & + & + \\
\hline \multirow[t]{2}{*}{14} & Trebouxia sp. 1 & Tre sp & & + & + \\
\hline & ULVOPHYCEAE & & & & \\
\hline 1 & Printzina lagenifera (Hildebrand) Thompson \& Wujek & Prin la & & + & + \\
\hline 2 & Trentepohlia abietina (Flotow) Hansgirg & Tren $a b$ & + & + & + \\
\hline 3 & Trentepohlia arborum (C. Agardh) Hariot & Tren ar & + & & + \\
\hline 4 & Trentepohlia diffracta (Krempelhüber) Hariot & Tren dif & & + & \\
\hline 5 & Trentepohlia rigidula (J. Müller) Hariot & Tren rig & + & + & + \\
\hline 6 & Trentepohlia sp. & Tren sp & & + & \\
\hline 7 & Trentepohlia sp. 1 & Tren 1 & + & & \\
\hline 8 & Trentepohlia sp. 2 & Tren 2 & + & & \\
\hline 9 & Trentepohlia sp. 3 & Tren 3 & & + & + \\
\hline 10 & Trentepohlia sp. 4 & Tren 4 & & + & + \\
\hline 11 & Trentepohlia sp. 5 & Tren 5 & + & & \\
\hline \multirow[t]{2}{*}{12} & Trentepohlia sp. 6 & Tren 6 & + & & \\
\hline & KLEBSORMIDIOPHYCEAE & & & & \\
\hline 1 & $\begin{array}{l}\text { Klebsormidium flaccidum (Kützing) Silva, Mattox, and Blackwell } \\
\text { ZYGNEMATOPHYCEAE }\end{array}$ & Kleb f & + & + & + \\
\hline 1 & Euastrum sublobatum var dissimile (Nordstedt) West and G. S. West & Eua sub & + & + & + \\
\hline 2 & Mesotaenium macrococcum (Kutzing ex Kutzing) J. Roy and bisset & Mes $\mathrm{m}$ & + & + & + \\
\hline 3 & Mesotenium sp. & Mes sp & + & & \\
\hline
\end{tabular}

humidity which favored cyanobacteria. Mawphlang sacred grove experienced low photon irradiance, high rainfall, and high relative humidity which influenced the high diversity of different groups of green algae and diatoms. Plantation in Golf Course correlated with high rainfall and photon irradiance which increased the abundance of Trentepohliales and green algae. Many cyanobacteria were strongly correlated with high photon irradiance while some other members on the other hand were influenced by rainfall, relative humidity, and temperature. Most of the members of Chroococcales 
TABLE 3: The results of SIMPER analyses illustrating species that differentiates among sampling areas.

\begin{tabular}{|c|c|c|c|c|}
\hline Taxon & $\begin{array}{c}\text { MSG } \\
\text { (Avg abundance) }\end{array}$ & $\begin{array}{c}\text { SGC } \\
\text { (Avg abundance) }\end{array}$ & $\begin{array}{l}\text { NH-44- Umiam } \\
\text { (Avg abundance) }\end{array}$ & Contribution \% \\
\hline Desmococcus olivaceus & 0.74 & 3.56 & 2.32 & 2.60 \\
\hline Trentepohlia abietina & 1.90 & 4.45 & 4.12 & 2.49 \\
\hline Chlorella sp. & 1.03 & 2.63 & 1.30 & 2.31 \\
\hline Scytonema sp. 1 & 0.00 & 0.00 & 2.88 & 2.27 \\
\hline Chlorella saccharophila & 0.30 & 2.55 & 0.93 & 2.10 \\
\hline Mesotaenium macrococcum & 0.84 & 2.89 & 1.11 & 2.08 \\
\hline Trentepohlia rigidula & 2.31 & 4.39 & 3.83 & 1.94 \\
\hline Trentepohlia sp. & 0.00 & 1.59 & 1.63 & 1.89 \\
\hline Trentepohlia sp. 2 & 2.23 & 0.00 & 0.00 & 1.87 \\
\hline Gloeocapsa punctata & 0.00 & 0.75 & 2.16 & 1.82 \\
\hline Chlorella sp. 1 & 0.62 & 1.48 & 1.36 & 1.80 \\
\hline Scytonema millei & 0.10 & 0.00 & 2.28 & 1.78 \\
\hline Euastrum sublobatum var dissimile & 0.41 & 1.97 & 0.00 & 1.57 \\
\hline Trebouxia arboricola & 0.83 & 1.60 & 1.08 & 1.53 \\
\hline Scytonema sp. & 0.23 & 0.75 & 1.62 & 1.52 \\
\hline Dictyochloropsis sp. & 0.00 & 1.83 & 0.00 & 1.47 \\
\hline Trentepohlia sp. 1 & 1.57 & 0.00 & 0.00 & 1.40 \\
\hline Gloeocapsa sp. & 0.00 & 0.32 & 1.70 & 1.39 \\
\hline Aphanocapsa muscicola & 0.00 & 0.59 & 1.59 & 1.37 \\
\hline Eunotia praerupta & 1.61 & 0.00 & 0.00 & 1.33 \\
\hline Podohedra saltans & 0.00 & 1.06 & 0.97 & 1.29 \\
\hline
\end{tabular}

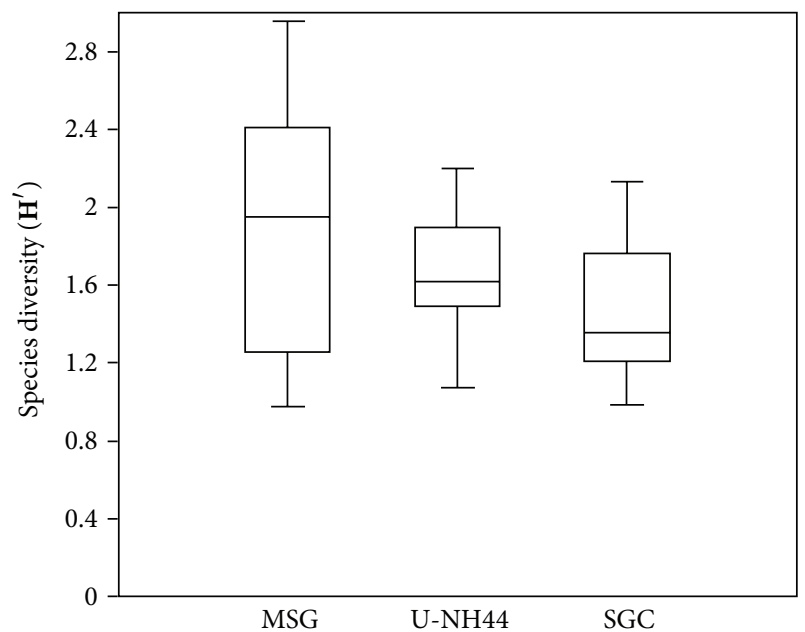

FIGURE 2: Boxplot of Shannon diversity index from January to December 2012 in the three sampling sites, that is, Mawphlang sacred grove (MSG), Umiam disturbed forest besides NH-44 (UNH44), and plantation in Shillong Golf Course (SGC).

their abundance were associated with high photon irradiance and high temperature except for Aphanothece sp. 1 whose abundance was associated with high rainfall. The abundance of most Nostocales members (Nostoc muscorum C. Agardh ex Bornet \& Flahault, Scytonema millei,and Scytonema sp. 1) was associated with high photon irradiance. Scytonema

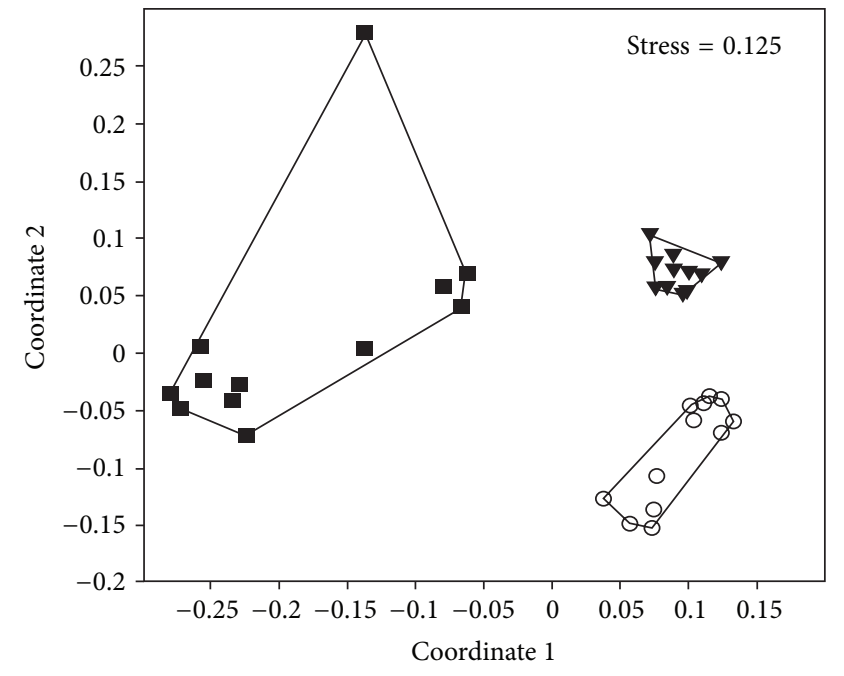

FIGURE 3: The nonmetric multidimensional scaling (nMDS) ordination diagram of sites according to species composition; filled square $(\boldsymbol{\square})$ indicates closed Mawphlang sacred grove; circle $(O)$ signifies open forest in Umiam NH-44; inverted triangle $(\boldsymbol{\nabla})$ signifies plantation in Shillong golf course.

sp. and S. Mirabile (Dillwyn) Bornet were influenced by high rainfall. Some Oscillatoriales members (Phormidium papyraceum (C. Agardh) Gomont and Symploca muscorum (C. Agardh)Gomont) were associated with high relative 


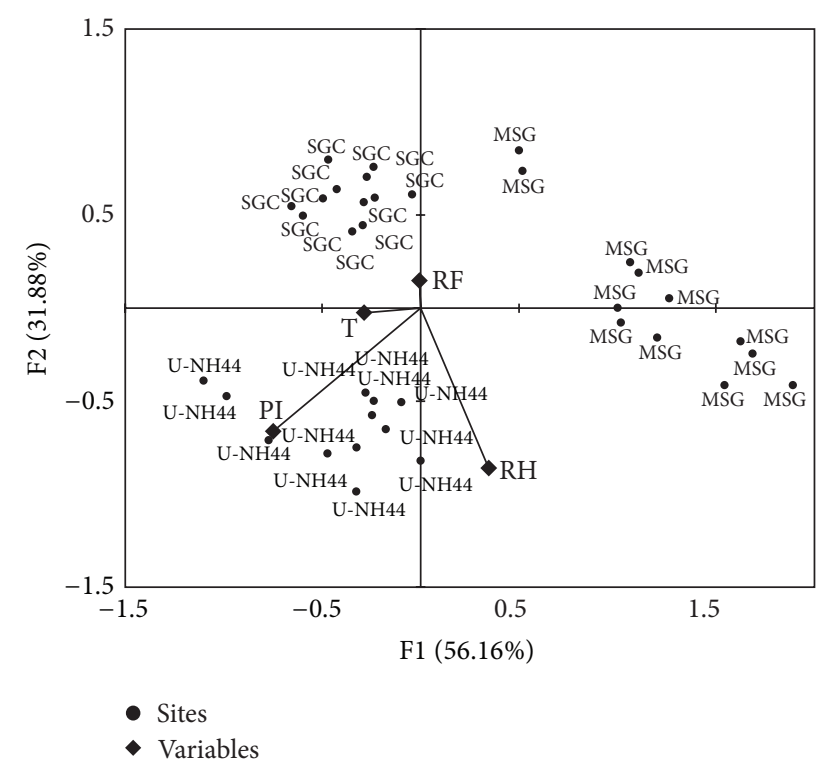

FIGURE 4: CCA (canonical correspondence analysis) ordination diagram of selected environmental gradients rainfall (RF), photon irradiance $(\mathrm{PI})$, relative humidity $(\mathrm{RH})$, and temperature $(\mathrm{T})$ correlated with different sites. Mawphlang Sacred Grove (MSG), disturbed forest in Umiam besides NH-44 (U-NH44), and plantation in Shillong Golf Course (SGC).

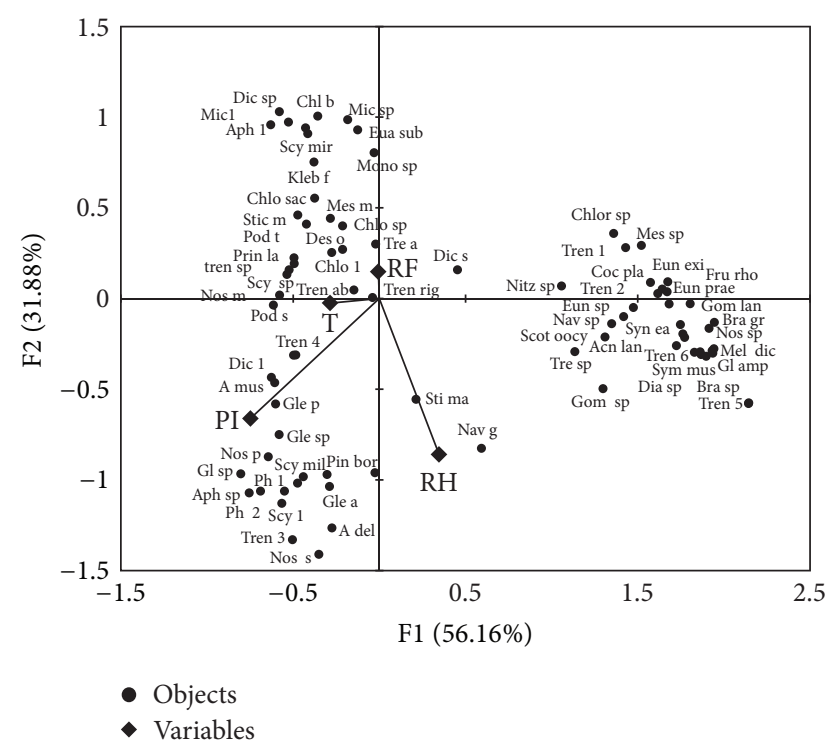

FIGURE 5: CCA (canonical correspondence analysis) ordination diagram of selected environmental gradients Rainfall (RF), photon irradiance (PI), relative humidity $(\mathrm{RH})$, and temperature $(\mathrm{T})$ correlated with algal assemblages. Species code is given in Table 2.

humidity. Diatoms abundances were correlated with high relative humidity and low photon irradiance except for Pinnularia borealis Ehrenberg which was influenced by high photon irradiance. Most of the Chlorophyceae members were influenced by high rainfall and relative humidity (Bracteacoccus grandis Bischoff \& Bold, Bracteacoccus sp. and Gloeocystis ampla (Kützing) Rabenhorst and some were influenced by photon irradiance and high rainfall (Chlorolobion braunii Nägeli Komarek). Trebouxiophyceae members were influenced by high rainfall and photon irradiance except for Dictyochloropsis sp. Dictyochloropsis splendida (Geitler) Tschermak-Woess and Trebouxia sp. which were associated with high relative humidity. High rainfall and high photon irradiance influenced the increased abundance of Trentepohliales members (Printzina lagenifera (Hildebrand) Thompson and Wujek, Trentepohlia sp, T. abietina, and T. rigidula). Trentepohlia sp. 5 and sp. 6 found in sacred groves were associated with high relative humidity. Desmids (Mesotaenium macrococcum and Euastrum sublobatum var dissimile) were associated with high rainfall and high photon irradiance.

\section{Discussions}

In the present study, enumeration of 85 taxa from different tree barks growing in three different ecological conditions confirmed the richness of subaerial algal communities in this region which is known for its rich floral diversity. Besides Trentepohliales and cyanobacteria other green algal groups were also common in tree barks of this region; hence, attention should also be given to these algal groups since they add to the overall knowledge on diversity of subaerial algae from any geographical area. The exclusive record of 27 algal taxa in closed undisturbed sacred grove which belonged mainly to Bacillariophyceae and green algae showed some interesting fact that sacred grove strategy not only conserve the tree species but every element within hence conserving the rich biodiversity. Besides the 55 identified taxa in sacred grove, there are some species which are awaiting confirmation in identification. It is expected that this Sacred Forest could house some subaerial algal species which might be new to science hence further taxonomical and molecular work should be carried out. In this study identification of species was done mainly on morphological criteria; however, Škaloud (2009) reported that identification based on morphological characters were adequate for standard ecological studies. High diversity observed in low photon irradiance area of closed sacred grove was in contrast to that found by Neustupa and Škaloud $[8,17]$ where diversity was more in open areas. Diversity was high in closed undisturbed sacred grove might be because of undisturbed nature, low photon irradiance, and high relative humidity which supported high number of diatoms and green algae. Low species abundance resulting in high evenness and low dominance index might be the other factors for high diversity in forest of Mawphlang sacred grove. Magurran [39] reported that diversity increased when dominance index was low and evenness index was high. Plantation in Golf course on the other hand showed dominance of mainly Trentepohliales members especially Trentepohlia abietina, and T. rigidula and therefore the diversity was low. In disturbed forest along NH-44 diversity was high due to the presence of many cyanobacteria which in turn increased the 
diversity. Strong significant differences observed in species composition of subaerial algal communities growing on tree barks in three different areas showed that sampling areas can also affect the species composition of subaerial algae. The differences in ecological parameters prevailing in the sampling areas could also play a role in determining the distribution of subaerial algae and cyanobacteria. The closed forest of Mawphlang sacred grove was characterised by mainly diatoms, 14 diatom species belonged to 10 genera (Achnanthes, Eunotia, Cocconeis, Diadesmis, Pinnularia, Frustulia, Gomphonema, Melosira, Navicula, and Nitzschia). Low photon irradiance, increased relative humidity, presence of mosses on the barks could be the possible reason for the growth of diatoms. Growth of many diatoms on terrestrial mosses has been reported by many workers [40-42]. They also demonstrated that moisture availability was an important factor for the growth of diatoms. Recording of 15 diatom species from the barks of different trees in the region was also high. Akinsoji [43] while working on bark micro flora of twelve tree species in southwestern Nigeria reported the presence of only 1 diatom species. Neustupa and Škaloud $[8,17]$ did not encounter any diatom species in their studies. Chandra and Krishnamurthy [24] reported 7 genera and 9 species of diatoms from Chennai, southern part of India and 6 species of diatoms from tree trunk and rocks at Yercaud Hill, Tamilnadu [25]. It is known from literature that subaerial microhabitats are mainly dominated by members of Trentepohliales and cyanobacteria since they could adapt to harsh environmental conditions by developing different strategies to survive, mainly by producing high carotenoids in Trentepohliales and forming a sheath composed of extracellular polymeric substances (EPS) outside in cyanobacterial cells as a protection against desiccation $[44,45]$. The finding here also proved that most cyanobacteria members especially Chroococcales and some taxa of Nostocales could grow well in areas with high photon irradiance so also was Trentepohliales where their abundance were more in plantation in Golf course and in open disturbed forest in Umiam compared to closed Mawphlang sacred grove which received low photon irradiance. The finding was also similar to that reported by Neustupa and Škaloud [17] where cyanobacteria and Trentepohliales dominated in open anthropogenic spaces. High abundance of Trentepohliales was found in samples from plantation in Golf course which explained that besides photon irradiance, and rainfall also played a very crucial role in distribution and abundance of Trentepohliales members especially Trentepohlia abietina and Trentepohlia rigidula and some desmids such as Mesotaenium macrococcum and Eustrum sublobatum var dissimile. Among the four environmental parameters, rainfall was a crucial variable. Islam [10] explained that very heavy rainfall and prevailing humidity provided ideal conditions for growth of subaerial algae the year around.

\section{Conclusions}

High diversity and record of 85 taxa in this region showed that this region is also rich in subaerial algal flora. Besides
Trentepohliales and cyanobacteria, other green algal groups and diatoms were common in tree barks of this region. Closed undisturbed sacred grove showed highest diversity than open disturbed forest and plantation. The study revealed that sampling areas with varied ecological variables played a great role in influencing the distribution and diversity of subaerial algal communities. Low photon irradiance, high relative humidity, and rainfall influenced positively the diversity of diatoms. Cyanobacteria members especially Chroococcales, some taxa of Nostocales, and Trentepohliales grew better in open areas receiving abundant sunlight which also showed their tolerance to high photon irradiance. Besides high photon irradiance, high rainfall also influenced the increased abundance of many Trentepohliales members. This study explained that subaerial algal diversity, abundance, and composition were all dependent on ranges of rainfall, photon irradiance, and relative humidity. Temperature had least effect on the diversity of subaerial algae. Hence, high rainfall in this region greatly influenced the diversity and abundance of subaerial algae.

\section{Conflict of Interests}

The authors declare that there is no conflict of interests regarding the publication of this paper.

\section{Acknowledgments}

The authors are thankful to northeastern Hill University for the financial support and to the Head of Botany Department for providing us all the laboratory facilities. They are also grateful to ICAR Barapani, Meteorological Centre Upper Shillong, and Directorate of Agriculture, Meghalaya Shillong, for providing them with environmental parameters data. They would also like to acknowledge Mr. Tambor Lyngdoh, the Exsecretary of Hima Mawphlang for giving them permission to collect samples from Mawphlang sacred grove and Mr. Bornlang Blah for his guidance and assistance during collection inside the grove.

\section{References}

[1] P. Hariot, "Notes sur le genre Trentepohlia Martius," Journals of Botany, vol. 3, pp. 128-149, 1889.

[2] E. de Wildemann, "Les Trentepohlia des indes neerlandaises," Annales du Jardin Botanique de Buitenzorg, vol. 9, pp. 127-142, 1890.

[3] E. de Wildemann, "Notes sur quelques espčces du genre Trentepohlia Martius," Annales Society of Belgian Microbiology, vol. 21, pp. 97-110, 1897.

[4] H. Printz, "Subaerial algae from South Africa," Kongelige Norske Vindenskabers Selskabs Skrifter, vol. 1, pp. 3-41, 1920.

[5] H. Printz, "Vorarbeiten zu einer monographie der trentepohliaceen," Nytt Magasin for Naturvidenskapene, vol. 80, pp. 137210, 1939.

[6] J. M. Lopez-Bautista, F. Rindi, and D. Casamatta, "The systematics of subaerial algae," in Extremophilic Algae, Cyanobacteria 
and Non-Photosynthetic Protists, from Prokaryotes to Astrobiology, J. Seckbach, Ed., Springer, New York Press, Berlin, Germany.

[7] F. Rindi, D. W. Lam, and J. M. López-Bautista, "Phylogenetic relationships and species circumscription in Trentepohlia and Printzina (Trentepohliales, Chlorophyta)," Molecular Phylogenetics and Evolution, vol. 52, no. 2, pp. 329-339, 2009.

[8] J. Neustupa and P. Škaloud, "Diversity of subaerial algae and cyanobacteria growing on bark and wood in the lowland tropical forests of Singapore," Plant Ecology and Evolution, vol. 143, no. 1, pp. 51-62, 2010.

[9] F. E. Fritsch, "A general consideration of the subaerial and freshwater algal flora of Ceylon," Proceedings of Royal Society, vol. 79, pp. 197-254, 1907.

[10] A. K. M. N. Islam, "Some subaerial algae from East Pakistan," Transactions of the American Microscopical Society, vol. 79, pp. 47-49, 1960.

[11] M. Akiyama, "On some Brazilian species of Trentepohliaceae," Memoirs of the Faculty of Education Shimane University. Natural Sciences, vol. 5, pp. 81-95, 1971.

[12] R. H. Thompson and D. H. Wujek, Trentepohliales: Cephaleuros, Phycopeltis and Stomotochroon Morphology, Taxonomy and Ecology, Science Publishers, Enfield, NH, USA, 1997.

[13] J. Neustupa, "The genus Phycopeltis (Trentepohliales, Chlorophyta) from tropical Southeast Asia," Nova Hedwigia, vol. 76, no. 3-4, pp. 487-505, 2003.

[14] J. Neustupa, "Investigations on the genus Phycopeltis (Trentepohliaceae, Chlorophyta) from South-East Asia, including the description of two new species," Cryptogamie Algologie, vol. 26, no. 3, pp. 229-242, 2005.

[15] F. Rindi and M. D. Guiry, "Diversity, life history, and ecology of Trentepohlia and Printzina (Trentepohliales, chlorophyta) in urban habitats in Western Ireland," Journal of Phycology, vol. 38, no. 1, pp. 39-54, 2002.

[16] F. Rindi, A. R. Sherwood, and M. D. Guiry, "Taxonomy and distribution of Trentepohlia and Printzina (Trentepohliales, Chlorophyta) in the Hawaiian Islands," Phycologia, vol. 44, no. 3, pp. 270-284, 2005.

[17] J. Neustupa and P. Škaloud, "Diversity of subaerial algae and cyanobacteria on tree bark in tropical mountain habitats," Biologia, vol. 63, no. 6, pp. 806-812, 2008.

[18] S. Handa and T. Nakano, "Some corticolous algae from Miyajima Island, Western Japan," Nova Hedwigia, vol. 46, pp. 165186, 1998.

[19] T. I. Mikhailyuk, "Eusubaerial algae of kaniv nature reserve (Ukraine)," Ukrainskii Botanicheskii Zhurnal, vol. 56, pp. 507$513,1999$.

[20] T. I. Mikhailyuk, P. M. Tsarenko, E. Nevo, and S. P. Wasser, "Additions to the study of aerophytic eukaryotic algae of Israel," International Journal on Algae, vol. 3, pp. 19-39, 2001.

[21] P. Bruhl and K. Biswas, "Indian bark algae," Journal of the Department of Science of Calcutta University, vol. 5, pp. 1-22, 1923.

[22] M. V. N. Panikkar and P. Sindhu, "Species of Trentepohlia from Kerala," Journal of Economic Taxonomic Botany, vol. 17, pp. 199204, 1993.

[23] V. Krishnamurthy, Algae of India and Neighboring Countries; 1 Chlorophycota, Oxford \& IBH, New Delhi, India, 2000.

[24] S. Chandra and V. Krishnamurthy, "Studies on succession of subaerial algae in culture," Indian Hydrobiology, vol. 3, pp. 24$38,2000$.
[25] S. Chandra, V. Krishnamurthy, M. D. V. Parthasarathy, and R. Rangarajan, "Subaerial algae, their altitudinal distribution and ecology at Yercaud, Tamilnadu," Indian Hydrobiology, vol. 8, pp. 151-155, 2005.

[26] S. Saharia, "New records of Trentepohlia from Assam, India," Advances in Plant Sciences, vol. 18, pp. 911-912, 2005.

[27] R. Mukherjee, S. P. Borah, and B. C. Goswami, "Biochemical characterization of carotenoids in two species of Trentepohlia (Trentepohliales, Chlorophyta)," Journal of Applied Phycology, vol. 22, no. 5, pp. 569-571, 2010.

[28] G. M. Smith, The Fresh Water Algae of the United States, McGraw-Hill Book, 1950.

[29] T. V. Desikachary, Cyanophyta, Indian Council of Agricultural Research, New Delhi, India, 1959.

[30] E. J. Cox, Identification of Freshwater Diatoms from Live Material, Chapman and Hall, London, UK, 1996.

[31] H. P. Gandhi, Fresh-Water Diatoms of Central Gujarat, Bishen Singh Mahendra Pal Singh, Shiva Offset Press, 1998.

[32] D. M. John, B. A. Whitton, and A. J. Brook, The Fresh Algal Flora of the British Isles, Cambridge University press, 2002.

[33] F. Rindi, M. D. Guiry, and J. M. López-Bautista, "New records of Trentepohliales (Ulvophyceae, Chlorophyta) from Africa," Nova Hedwigia, vol. 83, pp. 431-449, 2006.

[34] P. Škaloud, "Images from locality Boreč Hill," 2008, http://botany.natur.cuni.cz/skaloud/Borec.htm.

[35] P. Škaloud, "Species composition and diversity of aeroterrestrial algae and cyanobacteria of the Boreč Hill ventaroles," Fottea, vol. 9, no. 1, pp. 65-80, 2009.

[36] C. E. Shannon and V. Weaver, The Mathematical Theory of Communication, University of Illinios Press, Urbana, Ill, USA, 1963.

[37] O. Hammer, D. A. T. Harper, and P. D. Ryan, "PAST: paleontological statistics software package for education and data analysis," Palaeontologia Electronica, vol. 4, pp. 1-9, 2001.

[38] C. J. F. T. Braak, "Canonical correspondence analysis: a new eigenvector technique for multivariate direct gradient analysis," Ecology, vol. 67, no. 5, pp. 1167-1179, 1986.

[39] A. E. Magurran, Measuring Biological Diversity, Blackwell, Oxford, UK, 2004.

[40] L. Beyens, "Moss dwelling diatom assemblages from Edgeøya (Svalbard)," Polar Biology, vol. 9, no. 7, pp. 423-430, 1989.

[41] E. F. Round, R. M. Crawford, and D. G. Mann, The Diatom Biology and Morphology of Genera, Cambridge University Press, Cambridge, England, 1990.

[42] B. van de Vijver and L. Beyens, "The epiphytic diatom flora of mosses from Strømness Bay area, South Georgia," Polar Biology, vol. 17, no. 6, pp. 492-501, 1997.

[43] A. Akinsoji, "Studies on epiphytic flora of a tropical rain forest in Southwestern Nigeria," Plant Ecology, vol. 192, pp. 181-185, 1991.

[44] C. Urzi and M. Realini, "Colour changes of Noto's calcareous sandstone as related to its colonisation by microorganisms," International Biodeterioration and Biodegradation, vol. 42, no. 1, pp. 45-54, 1998.

[45] L. Tomaselli, "Biodeterioration processes on inorganic substrata," Coalition, vol. 6, pp. 5-9, 2003. 

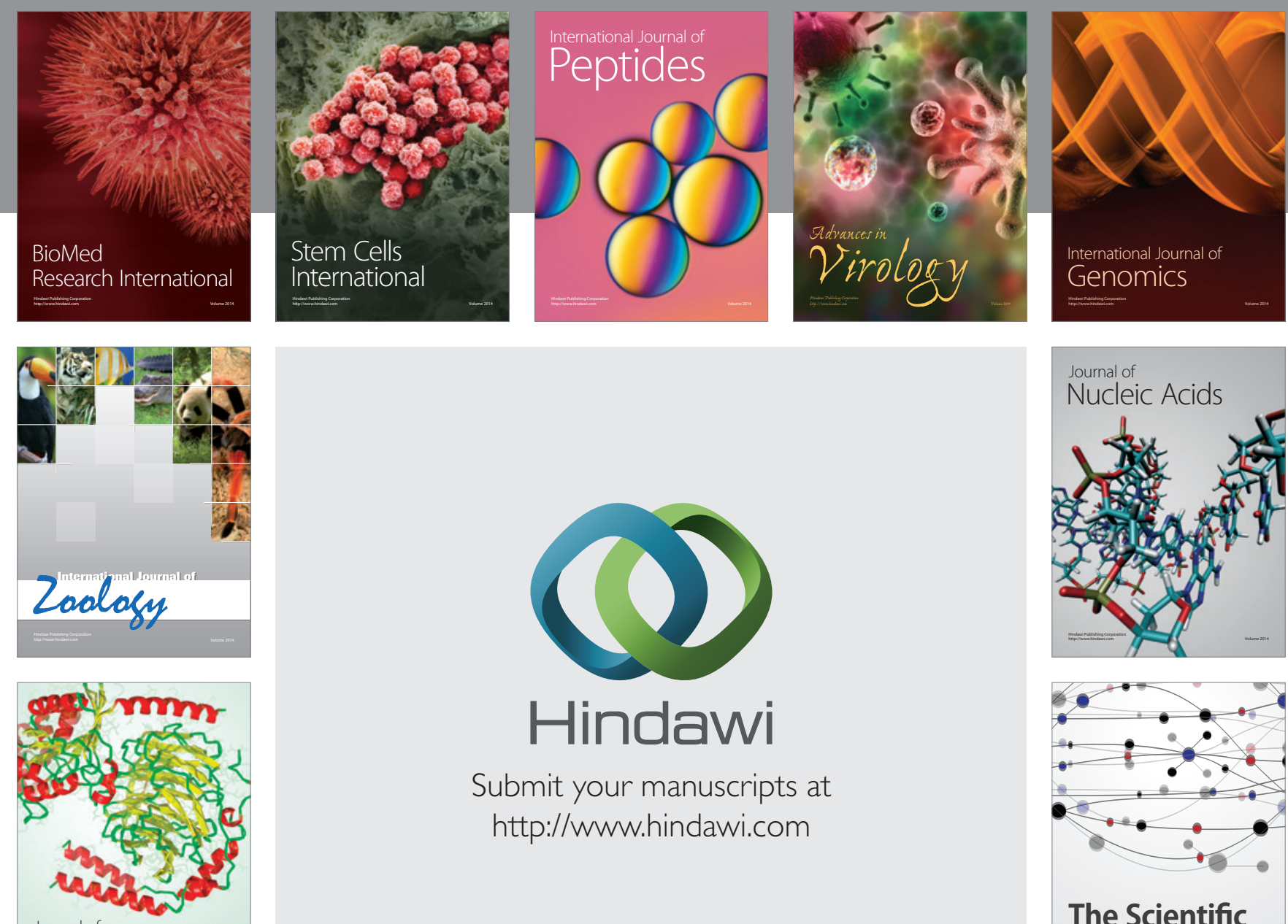

Submit your manuscripts at

http://www.hindawi.com

Journal of
Signal Transduction
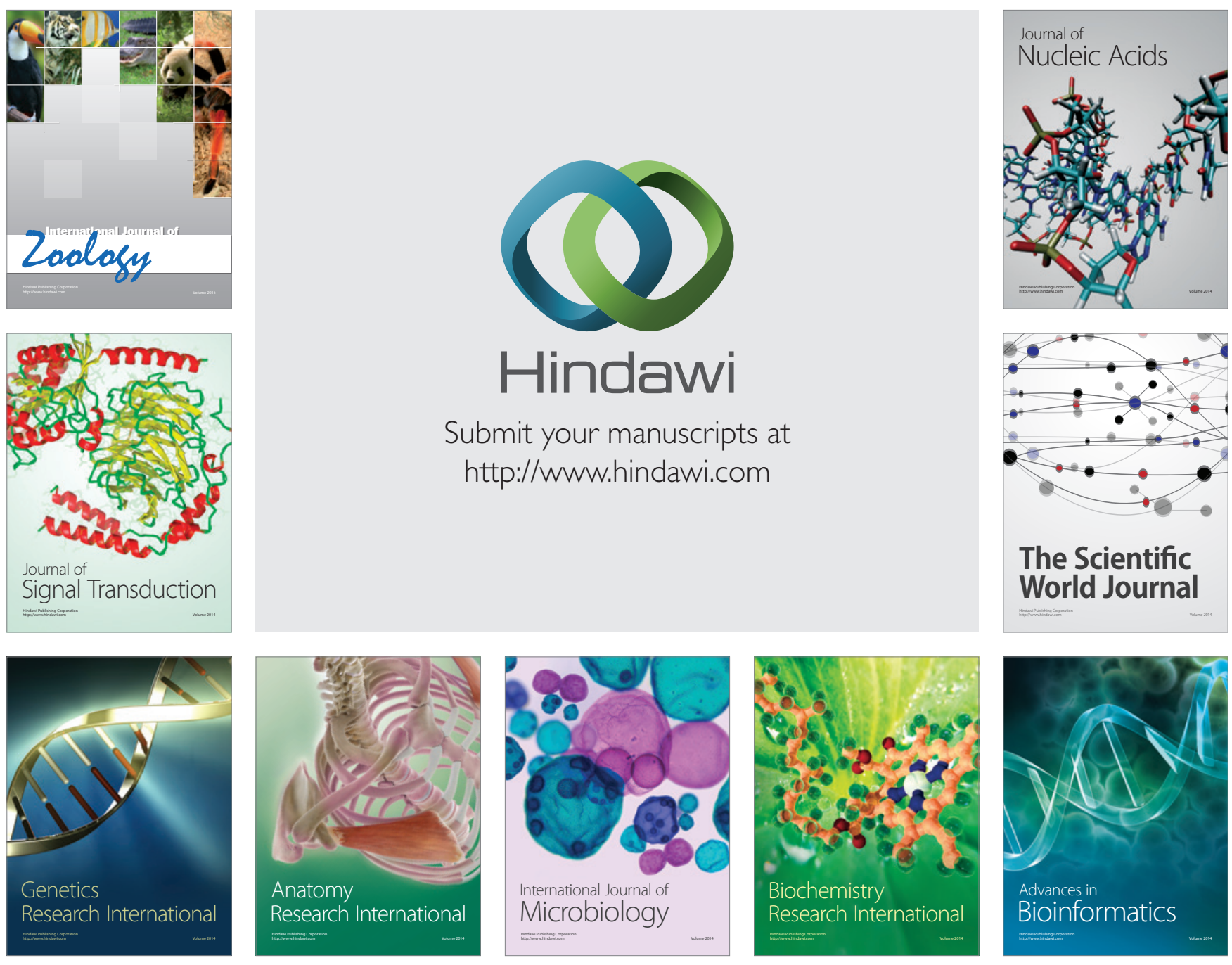

The Scientific World Journal
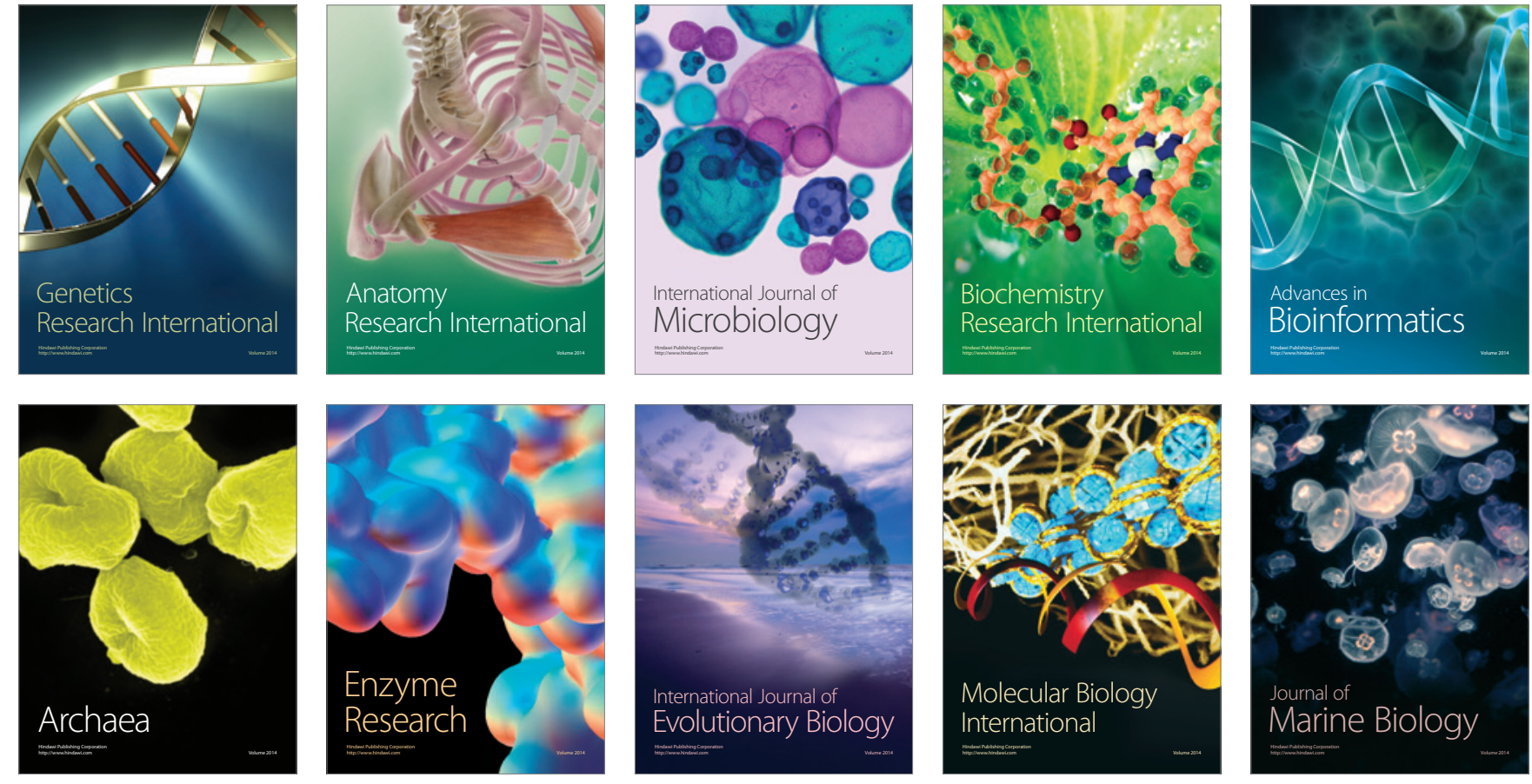